\title{
EFFECT OF OBSTRUCTIVE SLEEP APNEA (OSA) RISK LEVELS ON BOSTON NAMING TEST SCORES TO THE POPULATION IN MATARAM
}

\author{
Dwi Sulistyaningrum ${ }^{1}$, Rina Lestari ${ }^{1}$, Herpan Syafii Harahap ${ }^{1}$ \\ Correspondence: dwi08sulistya@gmail.com \\ ${ }^{I}$ Medical Faculty of Mataram University, Mataram, Lombok, Indonesia
}

\section{Article History: \\ Received: December 17, 2019 \\ Accepted: April 4, 2021 \\ Published: July 1, 2021}

\section{Cite this as:}

Sulistyaningrum D, Lestari $R$, Harahap HS. Effect of Obstructive Sleep Apnea (OSA)

risk levels on boston naming test scores to the population in

Mataram. Malang Neurology

Journal; 2021.7: 109-113.

http://dx.doi.org/10.21776/ub.mnj .2021.007.02.5

\section{ABSTRACT}

Background: Obstructive Sleep Apnea (OSA) is one of the most common respiratory disorders found in society. This condition is often found in men with obesity, men with hypertension history, and elderly. In relation to this, it is found that the researches on the effect of OSA risk level on language functions is rarely done. Therefore, this study is aimed at investigating the effect of OSA risk levels on Boston Naming Test score to the population in Mataram.

Objective: to investigate the effect of OSA risk levels on language functions used the Boston Naming Test to the population in Mataram.

Methods: This study belongs to analytic descriptive study with cross sectional approach. Held in Udayana Park, Dasan Sari, Mataram in May 2017 and September 2018. This study involved 132 respondents by ages among 40-74 years old. They are Chosen based on inclusion criteria. The OSA risk level was measured using The STOP-Bang questionnaire while language functions was measured using the Boston Naming Test. After That, the Mann-whitney comparative test was employed to analyzed the data.

Results: The result of this study showed that, from 132 respondents, it was found that there were 66 $(50 \%)$ respondents had a high risk level of OSA, and $82(62 \%)$ respondents had language function disorders. Besides, the Mann-Whitney comparative analysis showed no effect on the risk level of OSA on Boston Naming Test score ( $\mathrm{p}>0.05$ ).

Conclusion: The risk level of OSA has no effect on Boston Naming Test score to the population aged 40-74 years in Mataram.

Keywords: Obstructive sleep apnea, language function, stop-bang questionnaire, boston naming test

\section{Introduction}

Obstructive Sleep Apnea (OSA) is one of the most common respiratory disorders, affect almost $2-5 \%$ of the population in the Western country. ${ }^{1}$ In recent years, there has been a lot of research on OSA. Based on the epidemiological study of the Wisconsin Sleep Cohort Study in 1988-1994, found $4 \%$ men with OSA and $2 \%$ women with OSA. This prevalence increased in $2007-2010$ to $10-17 \%$ in men and $3-9 \%$ in women. ${ }^{2,3}$

Several OSA-related studies in Asia, such as In India a study had reported the prevalence of OSA as much as $7.5 \%$ in men and $4.5 \%$ in women. ${ }^{4}$ In Korea, patients with OSA is estimated at $36.5 \%$ and according to the data, men were higher than women. ${ }^{5}$ In Indonesia the prevalence of OSA still unknown, however, a study on a taxi company in South Jakarta showed that around $25 \%$ of drivers suffer from OSA. ${ }^{6}$ A cross sectional study in Mataram by Fatarosdiana et al showed patients with high risk of OSA more common in men than women. This prevalence is the same as previous studies. ${ }^{7}$

Research on OSA in Indonesia was rare, and the data was limited. ${ }^{8}$ That occur because of lack of knowledge and understanding of OSA, and difficulties in diagnosing OSA as well. ${ }^{9}$ Polysomnography (PSG) is gold standard for diagnosing OSA, but it is rarely done because limited availability of tools, requiring special expertise, expensive prices, and requires a lot of time because it is checked at night. ${ }^{10}$

There were several screening tools identify high-risk OSA, such as Epworth Sleepiness Scale (ESS), STOP Questionnaire, STOP-Bang Questionnaire, Berlin Questionnaire, Wisconsin Sleep Questionnaire, and Multivariable Apnea Prediction (MVAP). ${ }^{11}$ STOP-Bang questionnaire is one of screening tool that is most widely used, because it is easy to apply and has the highest sensitivity compared to other screening methods, as well as its validity has been proven by previous studies. ${ }^{12}$

Patients with OSA are not promptly treated can lead to a variety of conditions including cardiovascular disorders, metabolic syndrome, and impaired cognitive function. Decreased cognitive function in OSA has not been fully understood, but several studies suggest that there is a decline in cognitive function in OSA patients. ${ }^{13}$ Based on the Diagnostic and Statistical Manual of Mental Disorder (DSM-5), cognitive function disorders include attention, 
language, memory, visuospatial, executive, and social cognition disorders. ${ }^{14}$ The domain of cognitive function which the basic modality of cognitive is the language function. If there is a disruption in language function then other cognitive functions such as verbal memory and executive functions will interference as well. ${ }^{15}$

Language functions consist of 5 parameters, there are object naming, vocabulary, fluency, grammar, syntax, and receptive. ${ }^{14}$ There are several kinds of screening tools language functions, such as the Comprehensive Batteries which consist of Boston Diagnostic Aphasia Examination (BDAE), Western Aphasia Battery (WAB), psycholinguistics Assessment of Language Processing in Aphasia (Palpa), and the Comprehensive Aphasia Test (CAT). The specific examination to assess the naming function is the Graded Naming Test (GNT) and the Boston Naming Test (BNT). ${ }^{16}$ One of the most studied language function components is the naming function. Assessment of naming functions was carried out in normal subjects and atypical development subjects and those who suffering from neurological diseases such as aphasia, right hemisphere lesions, dementia, and brain injury, so that the instrument used was Boston Naming Test (BNT). ${ }^{17}$ BNT Instruments consisted of 15 items of objects with varying degrees of difficulty. ${ }^{18}$

Research related to OSA in Mataram has been done before, but the data of people with OSA in Mataram is still uncertain. This happens because of the lack of knowledge and understanding of the medical personnel and the public about OSA. Research on the effect of OSA risk level on naming functions has never been done in Mataram before. Therefore, the author wanted to examine the effect of OSA risk level on the naming function using the BNT score in the population in Mataram.

\section{Methods}

This study was a descriptive analytic study with cross sectional design to investigate the effect of the risk level of Obstructive Sleep Apnea (OSA) on the Boston Naming Test score in the population aged 40-74 years in Mataram. This research was conducted at Udayana Park, Dasan Sari Village, Mataram in May 2017 and September 2018. The independent variable of this study was the level of OSA risk and the dependent variable was the Boston Naming Test score.

Obstructive Sleep Apnea (OSA) risk level is the probability a person at risk of OSA in this study was assessed using the STOP-Bang questionnaire, which high risk of OSA if answered yes $\geq 3$ items and a low risk of OSA if answered yes $<3$ items. The Boston Naming Test (BNT) score is a score used to evaluate changes in a person's naming function. Data analysis to determine the effect of OSA on BNT scores using Mann-Whitney test, while to determine the relationship between other risk factors with BNT scores using chi-square test. Data collected will be presented in the table and the results are analyzed for the influence of OSA level on BNT scores.

\section{Results}

\section{The Subject Characteristics}

Data collection using a cross sectional study design, obtained total samples was $132(\mathrm{~N}=132)$. The avarage age of subjects in this study was 53.58 years, the proportion of late adulthood $(13.6 \%)$, early elderly $(51.5 \%)$, late elderly $(30.3 \%)$, and elderly (4.5\%). Most of the samples were female with a percentage of $53.8 \%$. The proportion of subjects to OSA risk level, whether high or low level of risk was the same amount $50 \%$ in both. In this study, the mean BNT score was $11.10 \pm 2.370$. (Table 1)

Table 1. Subject Characteristics

\begin{tabular}{cccc}
\hline Category & Sub-Category & \multicolumn{2}{c}{ Result $(\%)$} \\
\hline $\begin{array}{c}\text { Gender } \\
(\mathrm{N}=132)\end{array}$ & Man & 61 & $(46,2)$ \\
& Women & 71 & $(53,8)$ \\
Age & late adulthood (36-45 years old) & 18 & $(13,6)$ \\
& $\begin{array}{c}\text { early elderly (46-55 years old) } \\
\text { late elderly (56-65 years old) } \\
\text { elderly (>65 years old) }\end{array}$ & 68 & $(51,5)$ \\
Age in year & & 6 & $(30,3)$ \\
$($ mean \pm SD) & High & 53,58 & $\pm 7,531$ \\
Level risk of & Low & 66 & $(50)$ \\
OSA & & 66 & $(50)$ \\
$\begin{array}{c}\text { BNT Score } \\
(\text { mean } \pm \text { SD) }\end{array}$ & & 11,40 & $\pm 2,370$ \\
\hline
\end{tabular}

\section{Effect of OSA Risk Level on BNT Score}

Based on the STOP-Bang questionnaire, the OSA risk level was divided into high and low OSA risk levels, whereas for language function disorders was assessed from the number of BNT scores. After conducting the test, the value of $\mathrm{p}=$ 0.098 ( $p>0.05$ ), statistically there was no significant difference between the high risk level of OSA and the low risk of OSA on the BNT score. (Table 2)

Table 2. Effect of OSA Risk Level on BNT Score

\begin{tabular}{lccc}
\hline & $\mathrm{n}$ & $\begin{array}{c}\text { Median } \\
(\text { minimum- } \\
\text { maximum) }\end{array}$ & p-value \\
\hline $\begin{array}{l}\text { BNT score on high } \\
\text { risk of OSA }\end{array}$ & 66 & $11,5(5-15)$ & 0,098 \\
$\begin{array}{l}\text { BNT score on high } \\
\text { risk of OSA }\end{array}$ & 66 & $12,0(3-15)$ & \\
\hline $\mathrm{n}=$ number of samples; $\mathrm{p}$-value=significance value &
\end{tabular}

\section{Effect of Other Risk Factors on BNT Scores}

There are 5 other factors in this study that can influence BNT scores such as education level, hypertension, diabetes mellitus, smoking, and alcohol consumption. The BNT score is divided into 2 grup which is normal $(13-15)$ and impaired $(<13)$. After being analyzed, it was found that 2 risk factors that had a value of $p$ $<0.05$ were the level of education $(p=0.031)$ and hypertension $(p$ $=0.039$ ). These results indicate that both the factors of education and hypertension had effect on the BNT score, while other risk factors such as diabetes mellitus, smoking, and alcohol consumption get $\mathrm{p}$ value $>0.05$ which mean that there is no effect between these risk factors on the BNT score. (table 3)

\section{Discussion}

The purpose of this study was to investigate the effect of Obstructive Sleep Apnea (OSA) risk level on language function using the Boston Naming Test (BNT) score in the population aged 40-74 years in Mataram. STOP-Bang questionnaire, one of the screening tool was chosen as an 
instrument to measure the OSA risk level, because it has the highest sensitivity compared to other screening devices.19 This instrument has eight question parameters that easily understood and only require answers such as "Yes" and "No".

Table 3. Effect of Other Risk Factors on BNT Scores

\begin{tabular}{|c|c|c|c|c|c|c|}
\hline & & \multicolumn{4}{|c|}{ BNT Scores } & \multirow{3}{*}{$p$-value } \\
\hline & & \multicolumn{2}{|c|}{$\begin{array}{c}\text { Normal } \\
(\mathbf{n}=\mathbf{5 0})\end{array}$} & \multicolumn{2}{|c|}{$\begin{array}{c}\text { Impaired } \\
(\mathbf{n}=\mathbf{8 2})\end{array}$} & \\
\hline & & $\mathrm{N}$ & $\%$ & $\mathrm{~N}$ & $\%$ & \\
\hline \multirow{2}{*}{$\begin{array}{l}\text { Education } \\
\text { Level }\end{array}$} & $\begin{array}{l}\text { Formal } \\
\text { Education } \\
\leq 12 \text { tahun }\end{array}$ & 19 & 28,4 & 48 & 71,6 & $0,031 *$ \\
\hline & $\begin{array}{l}\text { Formal } \\
\text { Education } \\
>12 \text { tahun }\end{array}$ & 31 & 47,7 & 34 & 52,3 & \\
\hline \multirow{2}{*}{ Hypertension } & Yes & 5 & 33,3 & 10 & 100,0 & 0,784 \\
\hline & No & 45 & 38,5 & 72 & 61,5 & \\
\hline \multirow{2}{*}{ Smoking } & Yes & 13 & 36,1 & 23 & 63,9 & 0,843 \\
\hline & No & 37 & 38,5 & 59 & 61,5 & \\
\hline \multirow{2}{*}{$\begin{array}{l}\text { Alcohol } \\
\text { Consumption }\end{array}$} & Yes & 2 & 40,0 & 3 & 60,0 & 1,000 \\
\hline & No & 48 & 37,8 & 79 & 62,2 & \\
\hline
\end{tabular}

*P value is significant if $\mathrm{p}<0.05 ; \mathrm{n}=$ number of samples.

Language functions was assessed using BNT instruments which consisting of 15 image objects with varying difficulty levels including 5 easy items, 5 medium items, and 5 difficult items. ${ }^{18}$

Nowdays, a significant association between OSA and language functions is still unknown, but several studies suggest that both are related to the mechanism of intermittent hypoxia. Hypoxia causes interference of the blood brain barrier to maintain homeostasis, and that may lead to cognitive deficits due to synaptic plasticity impairments. $^{21}$

The results of this study showed that no significant effect of OSA risk level on BNT scores in the population in Mataram. Setyaningrum (2016) who analyzed the relationship between Obstructive Sleep Apnea Syndrome (OSAS) and cognitive function in stroke patients using a questionnaire (MoCA-Ina) showed different results. Bawden et al (2011) who evaluated OSA with Mini-Mental State Examination (MMSE) cognitive function, Brief Cognitive Screening Battery (BCSB), Digit-Symbol (DS) and Phonemic Verbal Fluency (PVF), also showed that OSA significantly cause global cognitive dysfunction, especially in the attention, memory, and executive functions. ${ }^{23}$ The difference in the results of the study was probably caused by using different instruments. Another cause of the result is not significant were the respondents' answers may not appropiate, the samples mostly women, the different screening tools and examiners as well, and unable to test the reliability of the blood measuring device and anthropometry (body height, weight, neck circumference).

Other instruments for assessing naming functions are Graded Naming Test (GNT), Visual Name Test (VNT), Category Specific Names Test (CSNT), and Action Naming Test (ANT). ${ }^{24}$ In this study, the authors used the BNT instrument because this instrument has excellent reliability and validity compared to other instruments, and has normal reference values available in various sources including Mayo's Older Americans Normative Studies (MOANS) and Older African American Normative Studies (MOAANS). 25
Nowdays, there are many studies using BNT instruments as research instruments, as in California a study of the effects of bilingual on the Boston Naming Test score, in Greece a study of the effects of age and education on naming functions, in France a study of the effects of bilingual adults on BNT scores, and in China regarding cultural effects on BNT performance. ${ }^{26-29}$

In Indonesia, research on the effects of OSA risk level associated with the naming function was still not found, so this research was the first study to evaluate the effects of OSA risk level associated with the naming function in Indonesia. In this study, the mean malfunctioning of the language based on BNT score higher on low risk OF OSA as much as 71.95, whereas the high risk of OSA as much as 61.05 , and the $\mathrm{p}$ value of 0.098 ( $\mathrm{p}$-value> 0.05 ) indicating that there were not significant differences between the two groups. There is no effect on OSA risk level on this BNT score. The risk level of OSA can be influenced by several factors such as gender, age, obesity, menopause, and ethnic. ${ }^{30}$ The BNT score can be influenced by other factors such as education level, physical inactivity, social isolation, smoking, alcohol consumption his study that in men there was an increase in fat deposits and had a longer pharyngeal size compared to women. Increased fat deposits cause collapse of the upper airway, resulting in a decrease in lung volume which increases the risk of OSA. ${ }^{33}$

About $67.4 \%$ of the sample in this study were $>50$ years old. As a person grows older, the muscles of the respiratory dilator will decrease in strength, increasing the risk of OSA. ${ }^{34}$ And also elderly suffer disturbance in sleep patterns related to circadian rhythms, this will increase the risk of OSA. ${ }^{35}$

In this study, $2.3 \%$ of the samples, hypertension, diabetes mellitus, atrial fibrillation, and metabolic syndrome. ${ }^{31,32}$ Based on this study, $50 \%$ of the samples who has high risk of OSA were found mostly in male $(70 \%)$, while $50 \%$ of the samples who has low risk of OSA were found mostly in women $(77 \%)$. These results can be concluded that the high risk of OSA is more common in men than women. These results are similar to previous studies in the United States and in several countries in Asia such as India and Korea, they found that the prevalence of OSA is more common in men than women. ${ }^{4}$ An imaging study stated in with $\mathrm{BMI}>35 \mathrm{~kg} / \mathrm{m} 2$ were found. Values of $\mathrm{IMT} \geq 30$ $\mathrm{kg} / \mathrm{m} 2$ indicate a person who has obesity. ${ }^{36}$ Several previous studies had stated that an increase in body size (BMI, waist-hip ratio, neck circumference) will cause an increase in the prevalence of OSA. Fat accumulation that occurs around the throat, chest, and abdomen lead to resistance or blockage in the respiratory tract. ${ }^{37,38}$ This can occur due to narrowing of the airway lumen caused by accumulation of fat tissue and decreased airway muscle strength due to fat deposits. ${ }^{39}$

In this study there were five factors that could influence BNT scores, those were the level of education, hypertension, diabetes mellitus, smoking, and alcohol consumption. After analyzing the five factors, it was found that there was an influence of education level and history of hypertension on BNT scores $(\mathrm{p}<0.05)$. The respondent with an education level $>12$ years had a normal BNT score of more than $47.7 \%$, whereas the formal education level $\leq$ 12 years was $28.4 \%$. This is caused by differences in 
Cognitive Reserve (CR) of each individual's cognitive abilities. Individuals with good CR has a brain networks more efficient, larger capacity, and more flexibility or more able to cope with disturbances in the brain. Education and experience of one's life have been proven to be able to increase individual cognitive reserve. ${ }^{40}$ Mansur et al (2006), states that a higher level of education will have a better naming function because it has more significant knowledge. ${ }^{17}$

In addition to the educational level, hypertension may also affect the score BNT. A study of the relationship between hypertension and cognitive function states that someone who has a history of hypertension will increase the risk of stroke. Stroke clinically can increase the risk of cognitive impairment and dementia. Hypertension also results in blood brain barrier dysfunction, resulting in the penetration of substances from the blood into brain tissue, this is related to an increase in the occurrence of amyloid $\beta$ deposits in blood vessels leading to the brain causing brain parenchyma damage. ${ }^{41}$

The limitation of this study were cross-sectional designs that are not good at assessing cause and effect, using tools and inspectors are different, and also lack of reliability testing of blood pressure and anthropometry measuring devices (height, weight, neck circumference). Research design to assess cause and effect is a cohort design. A cross-sectional design was chosen in this study because it takes a short time and a relatively low cost. This study will be better if further research follow-up on the same respondents using a cohort design.

\section{Conclusion}

The level of risk of Obstructive Sleep Apnea (OSA) does not affect the BNT score in the population aged 40-74 years in Mataram. There are other factors affecting BNT scores, those are education level and history of hypertension. Formal education level $\leq 12$ years and a history of hypertension increases the risk of impaired naming of language functions.

\section{Acknowledgement}

We would like to thank the research ethics commission, the academic community in medical faculty of Mataram University, research colleagues, and those who have helped in the preparation of this journal.

\section{Conflict of Interest}

The authors declare that there is no conflict of interst.

\section{References}

1. Matloba DP et al. Obstructive sleep apnoea: Epidemiology, quality of life, and management implication for dentist. The South African Dental Journal; 2015. 70(5):190-195. Available from : http://www.scielo.org.za/scielo.php?script=sci_arttext \&pid=S0011-85162015000500003.
2. Young T. et al. The occurrence of sleep-disordered breathing among middle-aged adults. N Engl J Med; 1993. 328(5):1230.

DOI: $10.1056 /$ NEJM199304293281704.

3. Peppard, P.E. et al. Increased prevalence of sleepdisordered breathing in adults. American Journal of Epidemiology; 2013. Vol. 177 No.9, pp.1006-1014. DOI: $10.1093 / \mathrm{aje} / \mathrm{kws} 342$.

4. Punjabi NM. The epidemiology of adult obstructive sleep apnea. Annals of The American Thoracic Society; 2008. 5(2):136-143. DOI: 10.1513/pats.200709-155MG.

5. Lee SD et al. The prevalence of and risk factors for sleep-disordered breathing in an elderly korean population. Respiration; 2014. 87:372-378. DOI: 10.1159/000358442.

6. Wiadnyana, IPGP. Prevalensi kemungkinan obstructive sleep apnea dan faktor-faktor yang berhubungan pada pengemudi taksi $\mathrm{x}$ di Jakarta. Jurnal Respirologi Indonesia, [online]; 2010. Available from:

http://jurnalrespirologi.org/jurnal/Jan10/OSApance\%20utk\%20majalah\%20JRI.

7. Fatarosdiana, Harahap HS and Padauleng N. Korelasi status kolesterol High-density Lipoprotein (HDL) serum dengan risiko Obstructive Sleep Apnea (OSA) pada penduduk kecamatan Sekarbela, Mataram, Indonesia. Cermin Dunia Kedokteran; 2017. 44(11):771-775. Available from : http://www.cdkjournal.com/index.php/CDK/article/vi ew/699/462.

8. Astuti $\mathrm{P}$ et al. Prevalensi dan gejala klinis Obstructive Sleep Apnea (OSA) pada pasien asma. Journal of the Indonesian Medical Association; 2011. 61:273-279. Available from https://fdokumen.com/document/pdf55cf9837550346 d033964ef4.html.

9. Jean-Louis G. Obstructive sleep apnea and cardiovascular disease: Evidence and underlying mechanisms. National Institutes of Health; 2009. 48(4):277-293. Available from : https://www.ncbi.nlm.nih.gov/pmc/articles/PMC3106 988/.

10. Park JG, Ramar K, and Olson EJ. Updates on definition, consequences, and management of obstructive sleep apnea. Mayo Clinic Proceedings; 2011. Vol 86 No 6, pp.549-555. DOI: 10.4065/mcp.2010.0810.

11. Jonas DE et al. Screening for obstructive sleep apnea in adults: An evidence review for the US preventive services task force. JAMA; 2017. 317(4);415-433. DOI: $10.1001 /$ jama.2016.19635.

12. Ramachandran SK, and Josephs LA. A meta-analysis of clinical screening tests for obstructive sleep apnea. Anesthesiology; 2009. 110(4):928-939. DOI: 10.1097/ALN.0b013e31819c47b6.

13. Kaffah S, and Susanto AD. Pengaruh Obstructive Sleep Apnea (OSA) terhadapfungsi kognitif. Jurnal Respirologi Indonesia; 2015. 35:247-259. Available from : http://arsip.jurnalrespirologi.org/wpcontent/uploads/2016/05/JRI_2015_35_4_247-59.pdf.

14. Sachdev PS et al. Classifying neurocognitive disorders: The DSM-5 approach. Nature Reviews 
Neurology; 201. 1-9. DOI: 10.1038/nrneurol.2014.181.

15. PERDOSSI. Modul Neurobehaviour. Program Pendidikan Dokter Spesialis Neurologi. Kolegium Neurologi Indonesia. Jakarta: Fakultas Kedokteran Universitas Indonesia. 2008.

16. Larner AJ. Neuropsychological neurology: The neurocognitive impairments of neurological disorders [e-book]. Cambridge University Press; 2008. Available From: https://books.google.co.id/books?isbn=0521717922.

17. Mansur LL et al. Boston naming test: Performance of Brazilian population from São Paulo, Pró-Fono Revista de Atualização Científica, Barueri (SP); 2006. 18(1):13-20. DOI: $\quad$ D.1590/S010456872006000100003.

18. PERDOSSI. Pemeriksaan neurologi dan neurobehavior untuk fit and proper test. Neurobehavior; 2016:1-28. Available from : https://www.scribd.com/document/425063833/FitProper-Test-2016.Wolfe RM, Pomerantz J, Miller DE, Weiss-Coleman $\mathrm{R}$, and Solomonides $\mathrm{T}$. Obstructive sleep apnea: Preoperative screening and postoperative care. J Am Board Fam Med; 2016;29:263-275.

DOI: $10.3122 /$ jabfm.2016.02.150085.

19. Chung, F. et al. High stop-bang score indicates a high probability of obstructive sleep apnoea. British Journal of Anaesthesia; 2011. 108(5):768-775.

DOI: $10.1093 / \mathrm{bja} / \mathrm{aes} 022$.

20. Lim DC, and Pack AI. Obstructive sleep apnea and cognitive impairment: Addressing the blood-brain barrier. Sleep Med Rev; 2014;18(1):1-31.

DOI: $10.1016 /$ j.smrv.2012.12.003.

21. Setyaningrum SD, Yunika K, and Andhitara Y. Hubungan antara fungsi kognitif dengan riwayat Obstructive Sleep Apnea Syndrome (OSAS) pada pasien pasca stroke iskemik di RSUP Dr Kariadi. JKD; 2017. 6(2):1237-1243.

DOI: $10.14710 /$ dmj.v6i2.18636.

22. Bawden, FC, Oliveira CA, and Caramelli P. Impact of obstructive sleep apnea on cognitive performance. Arq. Neuro-Psiquiatr; 2011. 69(4):585-589. DOI: $10.1590 /$ S0004-282X2011000500003.

23. Lezak MD et al. Neuropsychological assesment [ebook]. Oxford University Press; 2004. Available From:

https://books.google.co.id/books?id=FroDVkVKA2E C\&source $=$ gbs_similarbooks.

24. Sachs BC et al. Reliable change on the boston naming test. J Int Neuropsychol Soc; 2013. 18(2):375-378. DOI: $10.1017 / \mathrm{S} 1355617711001810$.

25. Gollan $\mathrm{TH}$ et al. The bilingual effect on boston naming test performance. Jurnal International Neuropsychological Society; 2007. 13:197-208. DOI: $10.1017 /$ S 1355617707070038 .
26. Patricacou A. et al. The boston naming test in Greek: Normative data and the effects of age and education on naming. Aphasiology; 2007. 21(12):1157-1170. DOI: $10.1080 / 02687030600670643$.

27. Sheppard C et al. Performance on the boston naming test in bilingual. International Neuropsychologycal Society; 2015. 22:350-363.

DOI: $10.1017 / \mathrm{S} 135561771500123 \mathrm{X}$.

28. Chen TB et al. Culture qualitatively but not quantitatively influences performance in the boston naming test in a chinese-speaking population. Dement Geriatr Cogn Disord Extra; 2014. 4:86-94. DOI: $10.1159 / 000360695$.

29. Lee W et al. Epidemiology of obstructive sleep apnea: A population-based perspective. Expert Rev Respir $\begin{array}{lll}\text { Med; } 2008 . & 2(3): 349-364 .\end{array}$ DOI: $10.1586 / 17476348.2 .3 .349$.

30. Sahatsevan R, Brodtmann A, and Donnan GA. Dementia, stroke, and vascular risk factors: A review. International Journal of Stroke; 2011. 7:61-73. DOI: 10.1111/j.1747-4949.2011.00731.x.

31. Larson EB. Risk factors for cognitive decline and dementia, uptodate [online]; 2018. Available from: https://www.uptodate.com/contents/risk-factors-forcognitive-decline-and-dementia\#H1.

32. Eckert DJ and Malhotra A. Pathophysiology of adult obstructive sleep apnea. Am Thorac Soc; 2008. 5:144153. DOI: $10.1513 /$ pats.200707-114MG.

33. Freidheim JM. Obstructive sleep apnea in severely obese subjects. Akademia Publishing, Norway; 2013.

34. Colten HR and Altevogt BM. Sleep disorders and sleep deprivation: An unmet public health problem [ebook]. National Academies Press (US); 2008. Available from: https://www.ncbi.nlm.nih.gov/books/NBK19956/.

35. World Health Organization. Obesity and overweight [online]; 2018. Available from: www.who.int.

36. Lee $\mathrm{W}$ et al. Epidemiology of obstructive sleep apnea: A population-based perspective. Expert Rev Respir Med; 2008. 2(3):349-364.

DOI: $10.1586 / 17476348.2 .3 .349$.

37. Stanford Health Care. Risk factor of obstructive sleep apnea. Stanford Medicine [online]; 2018. Available from: https://stanfordhealthcare.org/medicalconditions/sleep/obstructive-sleep-apnea/causes.html

38. Pillar G dan Lavie P. Obstructive sleep apnea: Diagnosis, risk factors and pathophysiology. Handbook of Clinical Neurology, Netherland. Elsevier; 2011. Part I Chapter 25. Third Edition. DOI: 10.1016/B978-0-444-52006-7.00025-3.

39. Stern, Y. Cognitive reserve. Neuropsychologia; 2009. 47(10):2015-2018.

DOI: 10.1016/j.neuropsychologia.2009.03.004.

40. Reitz C and Luchsinger JA. Relation of blood pressure to cognitive impairment and dementia. Curr Hypertens Rev; 2012;3(3):166-176. DOI: $10.2174 / 157340207781386747$. 